\title{
Why Do Western European Firms Issue Convertibles Instead of Straight Debt or Equity?
}

\author{
Marie Dutordoir and Linda van de Gucht
}

\begin{tabular}{|l|l|}
\hline \multicolumn{2}{|l|}{ ERIM REPORT SERIES RESEARCH IN MANAGEMENT } \\
\hline ERIM Report Series reference number & ERS-2006-056-F\&A \\
\hline Publication & October 2006 \\
\hline Number of pages & 40 \\
\hline Persistent paper URL & http://hdl.handle.net/1765/8043 \\
\hline Email address corresponding author & mdutordoir@rsm.nl \\
\hline Address & Erasmus Research Institute of Management (ERIM) \\
& RSM Erasmus University / Erasmus School of Economics \\
& Erasmus Universiteit Rotterdam \\
& P.O.Box 1738 \\
& 3000 DR Rotterdam, The Netherlands \\
& Phone: + 31104081182 \\
& Fax: $\quad+31104089640$ \\
& Email: info@erim.eur.nl \\
& Internet: www.erim.eur.nl \\
\hline
\end{tabular}

Bibliographic data and classifications of all the ERIM reports are also available on the ERIM website: www.erim.eur.nl 


\section{ERASMUS RESEARCH INSTITUTE OF MANAGEMENT}

\section{REPORT SERIES}

\section{RESEARCH IN MANAGEMENT}

\begin{tabular}{|c|c|}
\hline \multicolumn{2}{|c|}{ ABSTRACT AND KEYWORDS } \\
\hline Abstract & $\begin{array}{l}\text { Unlike their US counterparts, European convertible debt issuers tend to be large companies with } \\
\text { small debt- and equity-related financing costs. Therefore, it is a puzzle why these firms issue } \\
\text { convertibles instead of standard financing instruments. This paper examines European } \\
\text { convertible debt issuer motivations by estimating a security choice model incorporating } \\
\text { convertibles, straight debt, and equity. We find that European convertibles are used as } \\
\text { sweetened debt, not as delayed equity. This motivation is also reflected in the highly debt-like } \\
\text { design of most European convertible issues. In addition, we show that economy-wide and } \\
\text { country-specific factors have a significant incremental impact on the convertible debt choice. }\end{array}$ \\
\hline Free Keywords & Convertible Debt, Security Choice, Security Design, Western Europe \\
\hline Availability & $\begin{array}{l}\text { The ERIM Report Series is distributed through the following platforms: } \\
\text { Academic Repository at Erasmus University (DEAR), DEAR ERIM Series Portal } \\
\text { Social Science Research Network (SSRN), SSRN ERIM Series Webpage } \\
\text { Research Papers in Economics (REPEC), REPEC ERIM Series Webpage }\end{array}$ \\
\hline Classifications & $\begin{array}{l}\text { The electronic versions of the papers in the ERIM report Series contain bibliographic metadata } \\
\text { by the following classification systems: } \\
\text { Library of Congress Classification, (LCC) LCC Webpage } \\
\text { Journal of Economic Literature, (JEL), JEL Webpage } \\
\text { ACM Computing Classification System CCS Webpage } \\
\text { Inspec Classification scheme (ICS), ICS Webpage }\end{array}$ \\
\hline
\end{tabular}




\title{
Why Do Western European Firms Issue Convertibles Instead of Straight Debt or Equity?
}

\author{
Marie Dutordoir \\ Erasmus Universiteit Rotterdam, Department of Financial Management, 3000 DR Rotterdam, the \\ Netherlands \\ Email: mdutordoir@rsm.nl \\ Linda Van de Gucht \\ Katholieke Universiteit Leuven, AFI Leuven Research Center, 3000 Leuven, Belgium \\ Email: linda.vandegucht@econ.kuleuven.be
}

\begin{abstract}
Unlike their US counterparts, European convertible debt issuers tend to be large companies with small debt- and equity-related financing costs. Therefore, it is a puzzle why these firms issue convertibles instead of standard financing instruments. This paper examines European convertible debt issuer motivations by estimating a security choice model incorporating convertibles, straight debt, and equity. We find that European convertibles are used as sweetened debt, not as delayed equity. This motivation is also reflected in the highly debt-like design of most European convertible issues. In addition, we show that economy-wide and country-specific factors have a significant incremental impact on the convertible debt choice.
\end{abstract}

Keywords: convertible debt; security choice; security design; Western Europe.

This version: April 2006

We thank workshop participants at Columbia University, Erasmus Universiteit Rotterdam, Katholieke Universiteit Leuven, the 2004 FMA meeting, the 2004 EFMA meeting, the 2004 Belgian Financial Research Forum, and the 2004 Corporate Finance Day Ghent for insightful comments and suggestions. 


\section{Introduction}

Over the past decades, convertible debt has become a major source of financing for companies around the world. The literature offers several potential explanations for the use of convertible debt by corporations. On the whole, the existing theories represent two different viewpoints on convertible debt. Green (1984), Brennan and Kraus (1987), Brennan and Schwartz (1988), and Mayers (1998) perceive convertibles as sweetened debt instruments that are able to alleviate various debtrelated financing costs. Stein (1992), in turn, perceives convertible debt as delayed (or 'backdoor') equity financing that is well-suited for firms with high equity-related adverse selection costs.

Empirical evidence on the issuer motivations behind convertible debt offerings consists mainly of managerial surveys. Recent survey results (Billingsley and Smith, 1996; Graham and Harvey, 2001) provide evidence both for the sweetened debt and the delayed equity viewpoints on convertible debt. Lewis et al. (1999) study convertible debt issuer motivations in a more quantitative way, by developing a security choice model incorporating straight debt, convertible debt, and equity. They find that debt-like convertibles (i.e., convertibles with a small probability of being converted into equity) serve as sweetened debt instruments, whereas equity-like convertibles (i.e., convertibles with a high probability of being converted into equity) are used as delayed equity financing.

The above-mentioned empirical studies all focus on convertibles issued by US companies, and may thus reflect the specific characteristics of the US convertible debt market. Thus far, very little is known about the motivations for convertibles issued in other environments, such as the Western European market. This paper intends to fill this gap in the literature by studying the determinants driving Western European convertible debt issues.

The Western European convertible debt market provides an interesting laboratory for testing the validity of US-developed rationales on convertible debt for the following reasons. First, while this market only gained momentum since the 1990s, it has experienced a dramatic growth over the past fifteen years. ${ }^{1}$ Second, there are several striking differences between European and US convertible debt (issuers). As shown by Dutordoir and Van de Gucht (2004), European convertibles have a 
significantly larger debt component size than US convertibles. Moreover, whereas US convertible debt issuers are small, high-growth firms with high risk levels (Essig, 1991; Lewis et al., 1999, 2003), European convertible debt issuers tend to be very large, financially healthy, mature companies (Noddings et al., 2001; Bancel and Mittoo, 2004a; Dutordoir and Van de Gucht, 2004). Brennan and Schwartz (1988) literally state that: 'for large, mature corporations with strong credit ratings, there still appears to be no good reason for issuing convertibles'. Hence, the motivation for Western European companies to issue convertibles remains a puzzle.

This study aims to shed more light on the factors that induce Western European companies to issue convertible debt instead of standard financing instruments, by exploring a unique pan-Western European dataset of 419 straight debt issues, 179 convertible debt issues, and 214 equity issues made between 1994 and 2004. We use a similar security choice framework as in Lewis et al. (1999) to assess the validity of the sweetened debt and the delayed equity viewpoints on convertible debt in a European context. We also extend Lewis et al.’s (1999) analysis, however, by incorporating macroeconomic determinants as well as equity and straight debt market conditions in the security choice analysis. Moreover, we exploit the cross-country nature of our dataset to examine the influence of international differences in business laws on convertible debt issuance decisions.

To date, there are only two other papers in the literature that analyze European convertible debt issuer motivations, being the survey analyses of Bancel and Mittoo (2004a,b). ${ }^{2}$ Our study complements and extends Bancel and Mittoo's (2004a,b) analyses by focusing on observed managerial convertible debt choices rather than on managerial perceptions on convertible debt, and by differentiating between debt-like and equity-like convertibles. Our most important empirical results are the following.

First, we find that Western European companies use convertible debt mainly as a sweetened debt instrument, not as delayed equity financing. This is also reflected in the highly debt-like design of most Western European convertible offerings: the median conversion probability of these instruments is only $27.16 \%$, and very few issues are callable. Thus, whereas Lewis et al. (1999) obtain evidence both for the sweetened debt and the delayed equity viewpoints on convertible debt, our findings only support the former viewpoint. We identify both supply- and demand-related factors that might explain the differences in issuer motivations between European and US convertibles uncovered by our study. 
Second, we show that macroeconomic and security market conditions have a significant incremental impact over firm-specific characteristics on convertible debt choices. For example, we find that companies are more likely to substitute convertible debt for straight debt during periods with low straight debt issuance volumes (i.e., 'non-hot' straight debt markets). To the extent that these periods represent windows with higher economy-wide debt-related financing costs (as implied by the rationale of Bayless and Chaplinsky, 1996), this result provides additional support that Western European convertibles are used as sweetened debt issues.

Lastly, we find some evidence that convertible debt issuance decisions depend on the level of creditor and shareholder protection offered by the commercial law of the issuing firm's country of domicile. We also document that, all else equal, French firms are more likely than other Western European companies to issue convertible debt instead of straight debt or equity.

The remainder of this paper is structured as follows. In the next section, we provide an overview of the literature and develop the hypotheses. Section 3 describes the research methodology. Section 4 documents the security choice model results, and compares our findings with those obtained by other studies on the motivations for convertible debt offerings. Section 5 concludes the paper.

\section{Determinants of the choice between convertibles, straight debt and equity}

\subsection{Influence of firm-specific financing costs}

A number of theoretical rationales yield predictions on the firm types for which convertible debt offerings are most appropriate. Together, these rationales represent two different perceptions on the role performed by convertible debt.

Green (1984), Brennan and Kraus (1987), Brennan and Schwartz (1988), and Mayers (1998) model convertible debt as a suitable financing instrument for firms that wish to issue a debt-type security, but want to avoid some of the costs that would be associated with a straight debt financing. These models all assume that high equityrelated financing costs prevent firms from issuing equity. Their common starting point is a firm that needs to choose between issuing convertible debt or straight debt.

Green (1984) argues that convertible bonds are appropriate instruments for firms that want to mitigate asset substitution costs arising from the presence of risky debt. 
The underlying idea of his model is that, by adding a conversion option to their bond issues, firms allow bondholders to participate in the upside potential of their stock. Convertibles thus reduce the value of the stockholders' residual claim, thereby weakening the stockholders' tendency to engage in more risky projects. According to Brennan and Kraus (1987) and Brennan and Schwartz (1988), in turn, convertible debt can be used to mitigate adverse selection costs resulting from uncertainty about the current and future risk of the issuing firm. When there is such risk uncertainty, new bondholders will require an additional lemon's premium over the interest rate that they would normally ask if there were perfect information on firm risk. Brennan and Kraus (1987) and Brennan and Schwartz (1988) argue that companies can reduce this adverse selection problem by issuing convertibles instead of straight bonds. The reason why is that the negative impact of firm risk increases on the bond component of convertibles will be partly offset by the positive impact of firm risk increases on their equity component. As a result, the total value of convertible issues will be less affected by the issuing company's risk. Lastly, Mayers (1998) demonstrates that convertible debt is more suitable for financing a sequence of investment options of uncertain value than either short- or long-term bonds. On the one hand, convertibles are able to economize on the issue costs that would be associated with multiple shortterm debt offerings, since conversion leaves funds inside the firm. On the other hand, unlike long-term bonds, convertibles control for the stockholders' tendency to overinvest in projects with a negative NPV by returning the funds to bondholders through redemption when the investment option is not valuable. Unlike the previous three rationales, Mayers (1998) relies on the critical assumption that convertibles are callable. By calling their outstanding convertible debt, companies are able to force conversion of the convertible debt into equity when the investment option turns out to be valuable.

The above-cited models differ with respect to the specific debt-related financing costs that they consider to be mitigated by convertible debt, i.e., asset substitution costs in Green (1984), adverse selection costs resulting from uncertainty about firm risk in Brennan and Kraus (1987) and Brennan and Schwartz (1988), and overinvestment costs resulting from uncertainty about the value of a future investment project in Mayers (1998). Nevertheless, as will be discussed in Section 3, the variables that can be used to proxy these different debt-related financing costs are 
largely similar. Thus, we can only assess the collective validity of these models in our quantitative security choice analysis.

Whereas Green (1984), Brennan and Kraus (1987), Brennan and Schwartz (1988), and Mayers (1998) perceive convertibles as substitutes for straight debt, Stein (1992) perceives convertibles as substitutes for equity. More particularly, he models convertible debt as a suitable financing instrument for firms that have to issue an equity-type security because of prohibitively high financial distress costs, but want to avoid some of the adverse selection costs that would be associated with a common equity financing. Since convertible debt has a smaller equity component than equity, it is less likely to be perceived as a signal of firm overvaluation, thus inducing smaller adverse selection costs. Similar to Mayers (1998), Stein (1992) provides a critical role for the call provision in convertible debt. By calling their outstanding convertibles, issuers can force the bondholders to convert their bonds into shares in the near future, and thus obtain equity 'through the backdoor'.

Lewis et al. (1999) are the first to show that the above-discussed sweetened debt and delayed equity viewpoints on convertible debt are not mutually exclusive. They hypothesize that firms follow a two-step decision procedure when confronted with the choice between straight debt, convertible debt, and equity. In a first step, firms decide between issuing a debt-type security (straight debt or debt-like convertible debt) or an equity-type security (equity-like convertible debt or equity), depending on the relative magnitude of their debt- and equity-related financing costs. In a second step, within the debt-type security group, firms need to choose between debt-like convertible debt and straight debt. The latter choice menu corresponds with the setup of the sweetened debt rationales of Green (1984), Brennan and Kraus (1987), Brennan and Schwartz (1988), and Mayers (1998). As discussed earlier, these models all imply that firms with high debt-related financing costs should issue debt-like convertible debt instead of straight debt. Within the equity-type security group, in turn, firms need to choose between equity-like convertible debt and equity. This choice menu corresponds with the setup of the delayed equity rationale of Stein (1992). According to this rationale, firms with high equity-related adverse selection costs should prefer equity-like convertible debt over equity. Lewis et al. (1999) thus reconcile two, at first sight mutually exclusive theoretical viewpoints on convertible debt by subdividing the convertible debt universe into debt-like and equity-like convertibles. They 
hypothesize that the former instruments serve as sweetened debt issues, whereas the latter instruments serve as backdoor equity.

In this paper, we adopt a similar two-step security choice framework as in Lewis et al. (1999) to assess the validity of the sweetened debt and delayed equity viewpoints on convertible debt in a Western European context. We evaluate the joint validity of the sweetened debt rationales of Green (1984), Brennan and Kraus (1987), Brennan and Schwartz (1988), and Mayers (1998) by testing the following hypothesis: ${ }^{3}$

\section{Hypothesis H1a:}

Conditioning on a debt-type security choice, companies with high debt-related financing costs substitute debt-like convertible debt for straight debt.

In turn, we assess the validity of the delayed equity rationale of Stein (1992) by testing the following hypothesis:

\section{Hypothesis H1b:}

Conditioning on an equity-type security choice, companies with high equityrelated adverse selection costs substitute equity-like convertible debt for equity.

$$
<<\text { Insert Table } 1 \text { about here }>>
$$

Table 1 presents an overview of prior empirical evidence regarding the different theoretical rationales on convertible debt. ${ }^{4}$ Early survey results obtained by Pilcher (1955) and Brigham (1966) are mainly consistent with the delayed equity viewpoint. More recent survey analyses, however, report evidence both for the sweetened debt and the delayed equity rationales on convertible debt (Billingsley and Smith, 1996; Graham and Harvey, 2001). Lewis et al. (1999) shed more light on the mixed nature of these survey results by showing that convertibles can be used both as sweetened debt and as delayed equity, albeit not by the same firm types. More particularly, in line with their proposed security choice framework discussed above, they find that debt-like convertibles are issued as substitutes for straight debt by firms with high debt-related financing costs, whereas equity-like convertibles are issued as substitutes for equity by firms with high equity-related financing costs. 
The findings of Bancel and Mittoo (2004a,b) are very relevant in the context of our study, since these authors also focus on Western European firms. Bancel and Mittoo (2004a) obtain support for the two different viewpoints on convertible debt. Interestingly, their results indicate that the delayed equity motivation is more important for French firms than for other European companies. Bancel and Mittoo's (2004b) findings are mainly consistent with the delayed equity perception on convertible debt.

\subsection{Influence of economy-wide financing costs}

The above-discussed convertible debt rationales imply that a firm's decision to issue convertibles instead of straight debt or equity is driven by its own level of debtand equity-related financing costs. Several authors, however, argue that financing costs vary not only on a firm-specific level but also on an economy-wide level, e.g., due to temporal fluctuations in the availability of profitable investment opportunities and in the level of asymmetric information about firm value and firm risk (Choe et al., 1993; Bayless and Chaplinsky, 1996; Korajczyk and Levy, 2003; Krishnaswami and Yaman, 2004). For this reason, we include economy-wide debt- and equity-related cost measures in addition to firm-specific financing cost measures in our security choice analysis. Our testable hypotheses (conditional on the earlier-discussed two-step security choice framework proposed by Lewis et al., 1999) are the following:

\section{Hypothesis H2a:}

Conditioning on a debt-type security choice, companies substitute debt-like convertible debt for straight debt during periods with high economy-wide debtrelated financing costs.

\section{Hypothesis $H 2 b$ :}

Conditioning on an equity-type security choice, companies substitute equity-like convertible debt for equity during periods with high economy-wide equity-related financing costs.

In other words, we predict that companies use debt-like convertibles not only to sweeten high idiosyncratic debt-related financing costs but also to mitigate high 
economy-wide debt-related financing costs. Similarly, we expect that equity-like convertibles serve to alleviate both firm-specific and aggregate equity-related adverse selection costs.

Some studies (e.g., Choe et al., 1993; Korajczyk and Levy, 2003) use macroeconomic variables to measure temporal fluctuations in economy-wide financing costs. Bayless and Chaplinsky (1996), however, state that macroeconomic determinants are likely to omit some of the relevant financing costs faced by security issuers. They argue that security issuance volumes are more representative (inverse) proxies for economy-wide levels of financing costs, since companies time their security offerings during periods when these costs are lowest (thus giving rise to hot security market conditions).

Prior empirical evidence on the impact of aggregate financing costs on the choice between straight debt, convertible debt and equity is scarce and inconsistent. Lewis et al. (1999) report that companies are more likely to issue convertibles instead of straight debt when economic prospects (as measured by the leading economic indicator) are favorable. Krishnaswami and Yaman (2004), by contrast, find that companies substitute convertibles for straight debt when economic prospects are unfavorable and debt-related financing costs (as proxied by Treasury Bond yields) are high, which is in line with our hypothesis H2a. They do not examine the impact of economy-wide financing costs on the choice between convertible debt and equity, however. Lastly, Billingsley et al. (1988) find that, during hot equity windows, firms are more likely to issue equity instead of convertibles, and convertibles instead of straight debt. They do not incorporate macroeconomic conditions in their analysis. Our paper extends the above studies by simultaneously examining the impact of macroeconomic determinants and security market conditions on the choice between convertible debt, straight debt, and equity.

\subsection{Influence of creditor and shareholder protection rights}

Since La Porta et al.’s $(1997,1998)$ seminal papers, a large body of literature has studied the influence of commercial law on corporate financing choices. ${ }^{5}$ Korkeamaki (2005) is the first to examine the impact of international differences in business laws on the way in which convertibles are structured. He hypothesizes that firms domiciled in countries with weak shareholder protection and/or strong creditor protection rights 
design their convertibles to be more debt-like in nature, and obtains evidence consistent with this prediction. While Korkeamaki (2005) conditions on companies that have chosen to issue convertible debt, our paper also considers straight debt and equity as viable security choices. Similar to Korkeamaki (2005), we assume that investors domiciled in countries with weaker creditor (shareholder) protection rights prefer security types with a smaller debt (equity) component size, and that firms design their security offerings accordingly. We thus obtain the following hypotheses (again conditional on the sequential security choice framework discussed earlier):

\section{Hypothesis H3a:}

Conditioning on a debt-type security choice, companies domiciled in countries with weaker creditor protection rights substitute debt-like convertible debt for straight debt.

\section{Hypothesis H3b:}

Conditioning on an equity-type security choice, companies domiciled in countries with weaker shareholder protection rights substitute equity-like convertible debt for equity.

\section{Methodology}

\subsection{Sample construction}

The dataset used for testing the above hypotheses is constructed as follows. In a first step, we download lists of all straight debt, convertible debt, and equity offerings made by Western European industrial companies between January 1994 and December 2004 from Bloomberg Thomson Financial. We a priori exclude issues made by financial companies and utilities from our search, since the capital structure policy of such firms is often driven by regulatory aspects. In this way, we obtain a raw dataset of 879 bond offerings, 395 convertible debt offerings, and 677 equity offerings. 
In a next step, we impose the following criteria for inclusion in the final sample:

- The issuing company is headquartered in Western Europe (exclude subsidiaries of non-Western European firms);

- The issuing firm's accounting and stock price data for the fiscal year immediately prior to the announcement date are available on Datastream;

- Security-related data (e.g., conversion premium of the convertible debt issues, amount issued,...) are available on Bloomberg;

- The announcement and issue date of the offering are available on Bloomberg.

Subsequently, we impose a number of additional criteria on the individual security samples. We describe these requirements in detail in the Appendix.

After applying these filters, we are left with a final sample of 419 straight debt issues made by 256 firms, 179 convertible debt issues made by 148 firms, and 214 equity issues made by 192 firms.

Panel A of Table 2 presents the straight debt, convertible debt, and equity samples sorted by issue year. In line with previous studies (Choe et al., 1993; Bayless and Chaplinsky, 1996; Lewis et al., 2003), we find that there are substantial temporal fluctuations in equity and convertible debt offering volumes. There is also considerable time variation in the number of straight debt offerings. Following the rationale of Bayless and Chaplinsky (1996), these security volume fluctuations might reflect changes in aggregate levels of equity- and debt-related financing costs over time.

Panel B of Table 2 displays the three security samples sorted by country of domicile of the issuing company. The table reveals that more than $40 \%$ of the convertible debt issues are made by French firms. Earlier studies have also documented the dominance of France in the European convertible debt market (Ammann et al., 2003; Bancel and Mittoo, 2004a). In the straight debt sample, there is a large presence of issues made by companies domiciled in France (26.25\%) and the UK (20.29\%). The equity sample, in turn, comprises a very large number of offerings made by UK firms (37.38\%). In the security choice analysis, we will control for this geographical clustering within the security samples.

$<<$ Insert Table 2 about here $>>$ 


\subsection{Explanatory variables}

The explanatory variables included in our security choice analysis fall into three categories: firm-specific financing cost measures, economy-wide financing cost measures, and country-specific measures. Below, we specify the proxy variables belonging to each of these categories and report some descriptive statistics.

\subsubsection{Firm-specific financing cost measures}

Testing hypothesis H1a requires that we include proxies for the level of debtrelated financing costs of the security issuers in the analysis. To avoid a simultaneity bias, all characteristics are measured at fiscal year-end preceding the security announcement date, unless otherwise indicated.

Our first debt-related cost proxy is the leverage ratio, calculated as the ratio of total debt divided by total assets. Firms with a higher leverage have a higher potential for asset substitution and risk-related adverse selection costs (i.e., the debt-related financing costs considered by the models of Green, 1984; Brennan and Kraus, 1987; and Brennan and Schwartz, 1988). Moreover, a higher leverage enhances the attractiveness of convertible debt as a sequential-financing device, since potential savings from being able to reduce debt through calling the convertible should be larger when current leverage is higher (Mayers, 1998). As a second debt-related cost proxy, we include the daily stock return volatility. In line with Lewis et al. (1999, 2003), we measure this variable over the trading days -240 to -40 relative to the announcement date. Firms with a higher stock return volatility are assumed to face higher asset substitution and risk-related adverse selection costs. Moreover, such firms are likely to face more uncertainty regarding the value of future investment projects, which should make convertible debt more attractive as a sequential-financing vehicle. Our last debt-related cost measure is the ratio of taxes paid to total assets. In contrast with the previous two proxies, this variable is not directly related to specific convertible debt rationales, but rather to capital structure theory in general. Firms with a higher amount of tax liabilities benefit more from a debt(-type) issue, since interest payments can be deducted from corporate tax payments. The tax ratio thus acts as an inverse debt-related cost measure (Lewis et al., 2003).

Testing hypothesis H1b requires an assessment of the level of equity-related financing costs faced by the security issuers. The following standard proxy variables 
are used to capture these financing costs (see, for example, Lewis et al., 1999, 2003; Chang et al., 2004). The first equity-related cost measure is the amount of slack capital, calculated as the ratio of cash plus marketable securities divided by total assets. When a firm with sufficient slack capital issues securities, stockholders are more likely to infer that this firm is overvalued, since undervalued firms would rather resort to an internal slack financing. Therefore, firms with a large amount of slack capital are expected to incur higher equity-related adverse selection costs (Myers and Majluf, 1984). A second equity-related cost proxy is the issue size divided by the market value of equity measured one week prior to the announcement date. According to Krasker (1986), issues with large offering proceeds increase the potential for wealth losses by existing shareholders, and should thus be associated with higher adverse selection costs. As a last (inverse) equity-related cost measure, we include the preannouncement stock price runup. In line with Lewis et al. (1999, 2003), we measure this variable over the 75 trading days preceding the announcement date of the offering. We expect the stock runup to have a positive impact on the probability of a more equity-like security choice.

We also include two issuer characteristics that act as proxies for both debt- and equity-related financing costs in the analysis. First, we control for the availability of profitable growth opportunities by including the market to book ratio, calculated as the sum of total assets plus the market value of common equity minus the book value of common equity divided by total assets. Firms with a larger market to book ratio tend to have higher levels of asymmetric information about their (future) value and risk, and thus higher costs of attracting both straight debt and equity (Brennan and Schwartz, 1988; Lewis et al., 1999). Moreover, the availability of growth opportunities increases the likelihood that convertible debt will be used as a sequential-financing tool (Mayers, 1998). As a second control variable, we include the issuing firm size, measured as the natural logarithm of the book value of total assets. It is generally assumed that larger firms face smaller information asymmetries regarding their (future) value and risk, and hence lower debt- and equity-related financing costs (Brennan and Schwartz, 1988; Lewis et al., 1999).

Columns (1) to (3) of Table 3 provide an overview of the mean and median values of the above-cited firm-specific characteristics for the straight debt, convertible debt and equity samples. D ( $\left.\mathrm{D}^{-}\right)$denotes an (inverse) debt-related cost proxy, E (E־) denotes an (inverse) equity-related cost proxy. All variables are winsorized at $1 \%$. 
$<<$ Insert Table 3 about here $>>$

Comparing the descriptive statistics obtained for our Western European convertible debt sample with those provided by US-based studies reveals that European convertible debt issuers are substantially larger than their US counterparts. Whereas the typical US convertible debt issuer has an average (median) total assets size in the order of \$ 1 billion (\$ 300 million) (Mayers, 1998; Lewis et al., 1999, 2003; Krishnaswami and Yaman, 2004), we find that European issuers are on average more than five times as large. To the extent that firm size acts as an inverse proxy for the level of asymmetric information about firm value and risk, this observation suggests that European convertible debt issuers do not face high costs of attracting straight debt and equity financing, which is inconsistent with the profile of the typical convertible debt candidate suggested by the theoretical rationales described in Section 2. The total assets sizes recorded for our European straight debt and equity samples are also substantially higher than the sizes recorded for US straight debt and seasoned equity issuers, however. Thus, a large size seems to be a feature of European security issuers in general, rather than a specific characteristic of European convertible debt issuers. Pagano et al. (1998) suggest that the larger size of European security issuers is mainly attributable to a lack of legal enforcement rights for minority investors in Europe. This makes it hard for small and young European companies to get access to public capital markets.

Columns (4) and (5) of Table 3 provide t-test statistics for pairwise comparisons of convertible debt and straight debt issuers and convertible debt and equity issuers, respectively. For completeness, we also report univariate test results for a straight debt versus equity comparison in Column (6). According to the sweetened debt viewpoint on convertible debt, convertible debt issuers should face higher debt-related financing costs than straight debt issuers. Consistent with this prediction, we find that convertible debt issuers have a significantly higher stock return volatility and market to book ratio, and a significantly smaller total assets size than their straight debt issuing counterparts. They also have a significantly smaller leverage ratio than the straight debt issuers, however, which is not consistent with the sweetened debt perception. Convertible debt and straight debt issuers also differ with regards to their levels of equity-related financing costs. The t-statistics for the slack capital and the 
relative issue size indicate that convertible issuers have significantly higher equityrelated financing costs than straight debt issuers, which is not what we would expect based on the equity-linked nature of convertible debt. The finding that convertible debt issuers have a significantly higher pre-announcement stock runup than straight debt issuers is in line with our expectations, however.

Based on the delayed equity viewpoint on convertible debt, we expect convertible debt issuers to face higher equity-related financing costs than equity issuers. The results presented in Column (5) are inconsistent with this prediction, as they indicate that convertible debt issuers have a significantly smaller slack capital and market to book ratio, and a significantly larger total assets size than equity issuers. Of course, univariate test results as presented in Table 3 only enable a very crude assessment of the validity of the sweetened debt and delayed equity viewpoints. In the next section, we will use a more sophisticated two-step regression procedure for examining convertible debt issuer motivations in a multivariate context.

\subsubsection{Economy-wide financing cost measures}

As previously argued, we use both macroeconomic determinants and security issuance volumes to test hypotheses $\mathrm{H} 2 \mathrm{a}$ and $\mathrm{H} 2 \mathrm{~b}$. We include the 6-month leading indicator for the European economy (obtained from the OECD) as a general business conditions proxy. In line with Bayless and Chaplinsky (1996), we measure this variable as the average level of the index over the three months prior to the issue month relative to the average level of the index over the 12 months preceding the issue month. Since both debt- and equity-related financing costs tend to be lower during business expansions (Krishnaswami and Yaman, 2004), we cannot predict the impact of the leading indicator on the likelihood of a more debt-like security offering. The 5-year German Treasury Bond yield (obtained from International Financial Statistics) serves as a direct proxy for the economy-wide level of debt-related financing costs. ${ }^{6}$ Consistent with Choe et al. (1993), we express this variable as an average monthly yield calculated over the three months preceding the issue month. Our last macroeconomic explanatory variable is the runup in the daily return over the European equity market index (retrieved from Datastream). Choe et al. (1993) argue that periods with a high equity market return represent windows with smaller adverse selection costs, and hence a lower cost of raising equity(-linked) capital. In line with 
these authors, we measure the market runup over the 60 trading days prior to the beginning of the issue month.

In addition to the above macroeconomic determinants, we include a 'Hot Straight Debt' dummy variable equal to one for offerings issued during hot straight debt markets, and a 'Hot Equity' dummy variable equal to one for offerings issued during hot equity markets. According to Bayless and Chaplinsky (1996), hot equity markets represent periods with smaller aggregate equity-related adverse selection costs, since firms tend to time their equity offerings during periods when these costs are low. Following a similar line of reasoning, hot straight debt markets might represent periods with smaller aggregate debt-related financing costs. In the spirit of Bayless and Chaplinsky (1996), we define hot straight debt markets as three contiguous months during which the three-month moving average of the aggregate straight debt volume exceeds the upper quartile of a three-month moving average of the aggregate straight debt volume measured over the research window. Hot equity markets are determined in a similar way. ${ }^{7}$

\subsubsection{Country-specific measures}

In line with Korkeamaki (2005), we use the Creditor and Shareholder Rights Indices retrieved from La Porta et al. $(1997,1998)$ to capture the level of creditor- and shareholder-friendliness of our sample countries. The Creditor Rights Index (CRI) ranges between zero and four and measures the rights creditors have in bankruptcy. The Shareholder Rights Index (SRI) ranges between zero and five and measures the rights of minority shareholders. In order to avoid statistical problems caused by using an ordinal independent variable, we follow La Porta et al. (2000) and include a 'Creditorprotect' dummy variable equal to one if the CRI is above the sample median (2) instead of the actual CRI, and a 'Shareholderprotect' dummy variable equal to one if the SRI is above the sample median (2.5) instead of the actual SRI. To account for the geographical clustering documented in Panel B of Table 2, we also include a 'French' dummy variable equal to one for offerings made by French companies, and a 'UK' dummy variable equal to one for offerings made by UK companies. In this way, we want to ensure that the coefficients of the Creditorprotect and Shareholderprotect dummy variables do not reflect characteristics of the French or UK markets that are unrelated to the level of legal protection offered to creditors and shareholders. 


\subsection{Research design}

As noted earlier, we model convertible debt issuance decisions of Western European firms by means of the two-step security choice framework proposed by Lewis et al. (1999). In a first step, we analyze the impact of the above-discussed explanatory variables on the choice between straight debt, convertible debt, and equity. A very straightforward way of modelling this first-step regression analysis would be by estimating an ordered probit model with straight debt, convertible debt and equity as viable options. This methodology has the disadvantage, however, that it treats convertible debt as a homogeneous security class. In order to account for the varying levels of 'equity-likeness' of convertible debt issues, Lewis et al. (1999) conduct a logistic regression analysis in which the dependent variable is the probability that the security will be converted into equity at maturity. This probability is equal to one for equity, equal to zero for straight debt, and continuous on the interval ]0,1[ for convertibles. Thus, Lewis et al.’s (1999) first-step regression essentially estimates the likelihood of a more equity-like security choice, with equity and straight debt representing two extreme financing options and convertible debt offerings ranging from very equity-like issues (with a high conversion probability) to very debt-like issues (with a low conversion probability).

In line with Lewis et al. (1999), we use the conversion probability as dependent variable in our first-step security choice analysis. For convertible debt issues, this conversion probability is determined as $\mathrm{N}\left(\mathrm{d}_{2}\right)$, with $\mathrm{N}($.) the probability under a standard normal distribution function and $\mathrm{d}_{2}$ calculated as:

$$
d_{2}=\frac{\ln \left(\frac{S}{X}\right)+\left(r-\delta-\frac{\sigma^{2}}{2}\right) T}{\sigma \sqrt{T}}
$$

In the above equation, $\delta$ is the continuously compounded dividend yield for the fiscal year-end preceding the announcement date; $T$ is the initial convertible debt maturity (expressed in years); $S$ is the price of the underlying stock measured one week prior to the announcement date; $X$ is the conversion price; $r$ is the continuously compounded yield on a 5-year German Treasury Bond (measured on the announcement date); and $\sigma$ is the stock return volatility per annum. 
We obtain an average (median) conversion probability of 27.96 (27.16)\% for our Western European convertible debt sample, which is substantially smaller than the median conversion probability of 50.03\% recorded for the US convertibles studied by Lewis et al. (1999). Hence, we can conclude that the typical Western European convertible debt offering is structured to be more debt-like in nature than the typical US convertible debt offering. Since Bancel and Mittoo (2004a) report that French firms use convertibles more as delayed equity financing than do other European firms, we expect convertibles issued by French companies to exhibit a more equity-like structure. The average conversion probability of the French convertibles is not significantly different from that of the other Western European convertibles, however (t-statistic equals 1.45).

In a second and most important step of our empirical analysis, we examine what drives the security choice within the debt-type security subgroup (debt-like convertibles and straight debt) and the equity-type security subgroup (equity-like convertibles and equity), using the same explanatory variables as those included in the first-step analysis. The analysis of the debt-type subgroup enables us to evaluate the validity of the sweetened debt rationales of Green (1984), Brennan and Kraus (1987), Brennan and Schwartz (1988) and Mayers (1998), whereas the analysis of the equitytype subgroup allows us to assess the validity of the delayed equity rationale of Stein (1992).

In line with Lewis et al. (1999), we use the actual conversion probability to distinguish debt-like from equity-like convertibles. ${ }^{8}$ Lewis et al. (1999) label all convertible debt offerings with a conversion probability lower than 50\% debt-like, and all other convertibles equity-like. In this way, their convertible debt sample is almost evenly split between debt-like and equity-like issues. Using a similar criterion for our European sample, however, identifies only four convertibles as equity-like. Therefore, instead of the 50\% benchmark proposed by Lewis et al. (1999), we use the upper quartile of the conversion probability recorded for our sample issues (32.88\%) as a cutoff value for the debt-like versus equity-like classification. In this way, we identify 135 sample issues as debt-like and 44 sample issues as equity-like. In Section 4 , we discuss the robustness of our second-step regression results to the use of other measures for separating debt-like from equity-like convertibles. 


\section{Empirical analysis of the determinants of the convertible debt choice}

\subsection{Determinants of the choice between straight debt, convertible debt, and equity}

Table 4 reports the results of logistic regression analyses examining the choice between straight debt, convertible debt, and equity. As mentioned earlier, the dependent variable is the ex-ante probability that the security will be converted into equity at maturity. We thus expect debt-related financing cost proxies to exhibit a positive regression coefficient, and equity-related financing cost proxies to exhibit a negative regression coefficient (and vice-versa for inverse financing cost proxies). The impact of variables that act as (inverse) proxies for both debt- and equity-related financing costs cannot be predicted a priori.

$$
<<\text { Insert Table } 4 \text { about here }>>
$$

The regression model presented in Column (1) includes only firm-specific explanatory variables. Even though the model is parsimonious, it correctly classifies $74.50 \%$ of the financing decisions. This fraction is similar to the fraction of correctly classified observations obtained by papers examining the debt-equity choice (Marsh, 1982; Jung et al., 1996). The pseudo- $\mathrm{R}^{2}(22.41 \%)$ and the percentage of concordant responses (79.20\%) are slightly higher than the correspondent measures recorded by Lewis et al. (1999) (these authors do not mention the percentage of correctly classified observations obtained for their regressions).

An inspection of the Wald-statistics for the individual regression parameters reveals that firm size is by far the most significant determinant of the security choice of Western European firms. This finding confirms Brounen et al.'s (2004) survey results indicating that financing choices of Western European companies are predominantly determined by their sizes. The negative sign of the total assets coefficient suggests that larger firms resort to more debt-like security types, which is consistent with results obtained by US-based security choice papers (Jung et al., 1996; Lewis et al., 1999). Next to the highly significant impact of the firm size parameter, we also find that companies with a higher stock return volatility are significantly more likely to issue a more equity-like security type. Lewis et al. (1999) obtain a similar result. 
Column (2) of Table 4 displays the results of an extended security choice model in which we include economy-wide and country-specific measures. The regression coefficients and significance levels of the firm-specific variables remain largely unaffected by the inclusion of these additional explanatory variables. The findings with respect to the economy-wide and country-specific determinants are as follows. As expected, firms are significantly more likely to issue an equity-type security during periods with high interest rates. Moreover, firms are significantly more inclined to opt for an equity-like security during hot equity markets. The latter result supports Bayless and Chaplinsky's (1996) argument that hot equity markets represent windows of opportunity with a low aggregate level of equity-related adverse selection costs. Lastly, all else equal, companies domiciled in the UK are significantly more likely to choose an equity-like security type. This is consistent with our earlier observation that the equity sample is dominated by UK offerings (see Panel B of Table 2).

Two main conclusions emerge from the first-step security choice results reported in Table 4. First, in accordance with earlier studies (Marsh, 1982; Jung et al., 1996; Lewis et al., 1999), we find that security choices are partially predictable using preoffering information. Second, we find that macroeconomic determinants and security market conditions have a significant incremental impact over the firm-specific characteristics that are the traditional focus of security choice papers.

\subsection{Determinants of the choice between debt-like convertibles and straight debt}

To evaluate the validity of the sweetened debt viewpoint, we examine what motivates the choice between debt-like convertible debt and straight debt, while controlling for the factors that influence the likelihood of a debt-type security offering in general (i.e., the same determinants as those included in the first-step analysis). Table 5 displays the results of a logistic regression analysis with dependent variable equal to one for debt-like convertibles, and equal to zero for straight debt.

$<<$ Insert Table 5 about here $>>$

The goodness-of-fit statistics of the regression are very high (pseudo- $\mathrm{R}^{2}$ of $29.61 \%$, $87.00 \%$ of concordant observations, and $83.20 \%$ of correctly classified observations). Thus, despite the structural similarities between debt-like convertibles 
and straight debt, these securities seem to appeal to substantially different issuer clienteles. We now discuss the findings with regards to the three categories of explanatory variables included in the security choice model.

Following hypothesis H1a, we expect that, conditioning on a debt-type security choice, firms with high debt-related financing costs cluster into issuing convertibles instead of straight debt. In line with this hypothesis, we find that firms with a high stock return volatility are significantly more likely to substitute debt-like convertible debt for straight debt. This finding supports the rationales of Green (1984), Brennan and Kraus (1987), and Brennan and Schwartz (1988), which all imply that convertibles are capable of mitigating risk-related financing costs. It is also consistent with the sequential-financing rationale of Mayers (1998), to the extent that stock return volatility acts as a proxy for the level of uncertainty regarding the value of future investment options. Lewis et al. (1999) obtain a similar result in a US context. The firm-specific regression results equally indicate that companies with a smaller total assets size are significantly more likely to substitute debt-like convertible debt for straight debt. To the extent that smaller firms face higher debt-related financing costs, this result supports the four rationales representing the sweetened debt viewpoint on convertible debt. It is also in line with US-based findings obtained by Lewis et al. (1999). A last significant difference between debt-like convertible debt issuers and straight debt issuers pertains to their pre-issue stock price performance: debt-like convertible issuers have a significantly larger pre-announcement stock runup than straight debt issuers. This finding is consistent with the (small) equity component embedded in the former securities, as well as with results reported by Lewis et al. (1999).

The results on the impact of economy-wide financing cost measures on the propensity of a firm to substitute debt-like convertible debt for straight debt are as follows. First, we detect a significantly negative impact of the Hot Straight Debt dummy variable. Since hot straight debt markets are assumed to represent windows with a smaller aggregate level of debt-related financing costs, this finding is in line with hypothesis H2a. The other two aggregate debt-related financing cost proxies (i.e., the leading indicator and the German Treasury Bond yield) are both insignificant. The regression results also indicate that firms are significantly less likely to substitute debt-like convertibles for straight debt after a large stock market runup. This result is counterintuitive given the equity component embedded in debt-like convertibles. 
Lastly, we find that firms are significantly more inclined to issue debt-like convertibles instead of straight debt during hot equity markets. This result is consistent with our intuition, since the former instruments comprise a (small) equity component.

According to hypothesis H3a, firms domiciled in countries with a less creditorfriendly business law should be more inclined to substitute debt-like convertibles for straight debt. The results presented in Table 5 provide no evidence for this prediction, however, as the coefficient of the Creditorprotect dummy variable is not significantly different from zero. We do find a significantly negative impact of the Shareholderprotect dummy variable, which is counterintuitive given the (small) equity component embedded in debt-like convertibles. Table 5 also reveals that, all else equal, French firms are significantly more likely to substitute debt-like convertible debt for straight debt than are other European companies.

\subsection{Determinants of the choice between equity-like convertibles and equity}

To evaluate the validity of the delayed equity viewpoint on convertible debt, we examine the determinants of the choice between equity-like convertible debt and equity. Table 6 displays the results of a logistic regression analysis with dependent variable equal to one for equity-like convertibles and equal to zero for equity. The right-hand side variables are similar to those incorporated in the first-step security choice analysis. The security choice model has a very high classificatory power (pseudo- $\mathrm{R}^{2}$ of $36.25 \%, 92.20 \%$ of concordant observations, and $88.80 \%$ of correctly classified observations). Thus, despite the fact that equity-like convertibles and equity have similar design characteristics, there seem to be substantial differences in the determinants driving these two security types.

$$
<<\text { Insert Table } 6 \text { about here }>>
$$

Following hypothesis H1b, we expect that, controlling for the factors driving an equity-type offering, companies with high equity-related adverse selection costs issue equity-like convertible debt instead of equity. Table 6 reveals, however, that none of the firm-specific equity-related cost proxies has a significant impact on the choice between equity-like convertibles and equity. Thus, we obtain no support for the 
validity of the delayed equity rationale of Stein (1992) in a Western European context. The only significant difference between equity-like convertible debt issuers and equity issuers pertains to their stock return volatility: firms with a higher stock return volatility are significantly less likely to issue equity-like convertible debt instead of equity. Thus, whereas Table 5 suggests that debt-like convertible debt serves as an instrument to alleviate costs resulting from a high firm-specific risk level, Table 6 indicates that equity-like convertible debt is not used for this purpose. Lewis et al. (1999) obtain a similar finding in a US context.

Hypothesis H2b states that, during periods with high equity-related adverse selection costs, companies are more likely to issue equity-like convertible debt instead of equity. The results displayed in Table 6 partially support this prediction. On the one hand, we find that firms are significantly less inclined to substitute equity-like convertibles for equity during hot equity markets. Since hot equity markets are assumed to represent windows with a smaller level of equity-related financing costs (Bayless and Chaplinsky, 1996), this finding is consistent with hypothesis H2b. On the other hand, we also find that companies are significantly more likely to issue equity-like convertibles instead of equity when economic prospects (as proxied by the leading indicator) are more favorable. To the extent that the leading indicator acts as an inverse measure for the economy-wide level of equity-related financing costs, this result does not support hypothesis H2b.

Following hypothesis H3b, firms domiciled in countries with weaker (stronger) shareholder protection rights should be more (less) inclined to substitute equity-like convertibles for equity. Consistent with this prediction, Table 6 indicates that the Shareholderprotect dummy variable has a significantly negative impact on the propensity of a firm to issue equity-like convertibles instead of equity. We also record a significantly negative influence of the Creditorprotect dummy variable, however, which is hard to reconcile with the (small) debt component embedded in equity-like convertible debt. Lastly, we find that French firms are significantly more likely to issue equity-like convertibles instead of equity than are other Western European companies. Combining the latter result with the significantly positive parameter of the French dummy variable in Table 5, we can conclude that French firms have a larger preference for convertible debt in general, both as a substitute for straight debt and as a substitute for equity. Importantly, this finding cannot be attributed to particular firm, 
economy-wide or business law characteristics associated with French convertible offerings, since the regressions appropriately control for these factors.

\subsection{Robustness of results to other equity component measures}

The probability of conversion has the advantage that it simultaneously incorporates several convertible debt design features, thus providing a more complete picture of the equity-likeness of a convertible debt offering than do individual design parameters. Moreover, unlike design features that do not exist for straight debt and equity offerings (e.g., the conversion premium), the probability of conversion can be used both in the first- and the second-stage regressions since it is equal to zero (one) for straight debt (equity). A drawback of this equity component measure, however, is that it does not take into account whether a convertible is callable. Similar to the probability of conversion, the presence of a call feature might be an important indicator for the underlying motivations behind a convertible debt offering. As argued in Section 2, firms that want to use convertible debt as a delayed equity instrument or as a sequential-financing tool are more likely to add a call feature than firms that want to use convertible debt to reduce asset substitution or risk uncertainty costs. It turns out that only $16.76 \%$ of the convertibles in our dataset have a call feature, which casts doubt on the validity of the models of Stein (1992) and Mayers (1998) in a Western European context. US convertibles, by contrast, are almost always callable (Lewis et al., 1998).

To test the robustness of our findings to the use of the call feature as an alternative equity component measure, we reconduct the second-step regressions with debt-like (equity-like) convertibles defined as issues without (with) a call feature. The results of these regressions (not reported for parsimony) are very similar to the results obtained by means of the conversion probability. This is logical, since there is a significant connection between the presence of a call feature and the magnitude of the conversion probability of European convertibles: convertibles with a call feature have a significantly higher conversion probability than convertibles without a call feature (tstatistic equals 2.47). Our main conclusions also remain similar when we use the conversion premium (i.e., a less sophisticated equity component measure than the conversion probability) to separate debt-like from equity-like convertibles. We can 
thus conclude that our findings are not dependent on the specific benchmark used for the debt-like versus equity-like convertible debt classification.

\subsection{Comparison with other studies}

On the whole, the regression results displayed in Tables 5 and 6 suggest that European convertibles are used to alleviate firm-specific debt-related financing costs, but not to mitigate firm-specific equity-related financing costs. Hence, while USbased papers obtain support both for the sweetened debt and the delayed equity viewpoints on convertible debt (Billingsley and Smith, 1996; Lewis et al., 1999; Graham and Harvey, 2001), our European results only support the former viewpoint.

The divergence between our findings and the results obtained by US-based papers on convertible debt issuance motivations might be driven by supply-side differences between European and US convertible debt markets. More particularly, as noted earlier, European convertible debt issuers tend to be very large, mature companies. Such firms are likely to have more debt capacity than the small, high-risk, highgrowth firms dominating the US convertible debt issuer universe. According to the pecking order model of Myers and Majluf (1984), firms choose risky debt over equity provided that they have the necessary debt capacity. Thus, a first explanation for the highly debt-like structure of most European convertible debt issues might be the larger debt capacity of European convertible debt issuers relative to US issuers. Of course, given this large debt capacity, it could be questioned why European convertible debt issuers do not tap the straight debt market instead. The regression results displayed in Table 5 provide an answer to this question. More particularly, these results reveal that, even though European convertible debt issuers might have smaller debt-related financing costs than their US counterparts, they still have significantly higher debt-related financing costs than European straight debt issuers. Adding an (albeit small) conversion option to their debt offering might enable these companies to raise debt capital on more favorable terms than if they would issue 'plain vanilla' straight debt.

The differences in motivations between European and US convertible debt issuers might equally be driven by demand-side differences between European and US convertible debt markets. For example, in an article in Corporate Finance (2001), we read: 'In the US, convertibles have been - and still are - an equity play. The 
investment banks that deal in the product normally locate their teams on the same floor as the stock guys, and investors generally come from an equity background. All this makes perfect sense in a market where venture capital and investment risk-taking is part and parcel of the culture. European investors prefer stronger, more established credits, and generally look upon the convertibles market as an extension to the bond market.' In other words, European convertible debt issuers might structure their offerings as sweetened debt issues in order to cater to the bond mentality of their investor base.

A priori, we expected our conclusions to be highly similar to the survey results obtained by Bancel and Mittoo (2004a), who also focus on Western European convertible debt issuers. ${ }^{9}$ We effectively detect some striking similarities between their and our results. For example, Bancel and Mittoo (2004a) document that 70\% of their respondents consider straight debt as an alternative for convertible debt, whereas only $23 \%$ consider equity as an alternative. This finding supports our conclusion that Western European firms use convertibles mainly as a substitute for straight debt. Moreover, while Graham and Harvey (2001) report that the ability to force conversion by calling the convertible debt is an important motivation for US convertible debt issuers, Bancel and Mittoo (2004a) obtain only modest support for this motivation among European issuers. This finding is consistent with our conclusion that Western European firms do not use convertibles as backdoor equity financing.

Our results also differ from Bancel and Mittoo’s (2004a) findings on several dimensions, however. Most importantly, Bancel and Mittoo (2004a) document that about $86 \%$ of the European CFOs participating in their survey rank the delayed equity motivation as (very) important, whereas we do not obtain any evidence for the validity of the delayed equity viewpoint on convertible debt in a European context. Moreover, we find that the equity component size of French convertibles is not significantly larger than that of other European issues, which is inconsistent with Bancel and Mittoo's (2004a) observation that the delayed equity motivation is more important for French firms than for other Western European companies. These divergences are probably attributable to the use of a different research methodology, i.e., a detailed survey analysis of 29 respondents in Bancel and Mittoo (2004a) versus a large-sample quantitative security choice analysis in the present paper. 


\section{Conclusion}

This paper evaluates the validity of US-developed rationales on convertible debt in a Western European context. We test the sweetened debt rationales on convertible debt (Green, 1984; Brennan and Kraus, 1987; Brennan and Schwartz, 1988; Mayers, 1998) by comparing debt-like convertible debt issuers to straight debt issuers, and the delayed equity rationale on convertible debt (Stein, 1992) by comparing equity-like convertible debt issuers to equity issuers.

Our study uncovers substantial differences in the factors driving European and US convertible debt issuance policies. In particular, whereas Lewis et al. (1999) report that US convertibles are used both as sweetened debt and as delayed equity (albeit not by the same firm types), our evidence is only consistent with the sweetened debt rationales of Green (1984), Brennan and Kraus (1987), and Brennan and Schwartz (1988). We identify both supply- and demand-side differences between the Western European and US convertible debt markets that might explain the divergence between our results and Lewis et al.’s (1999) US-based findings.

We also extend Lewis et al.'s (1999) analysis by examining the influence of economy-wide financing costs on the choice between convertible debt, straight debt, and equity. We find that companies substitute debt-like convertible debt for straight debt during periods with a high economy-wide level of debt-related financing costs. Thus, debt-like convertibles are not only used to alleviate high firm-specific debtrelated costs, but also to sweeten high economy-wide debt-related costs. We also obtain some evidence that companies substitute equity-like convertible debt for equity during periods with a high economy-wide level of equity-related financing costs.

In addition, we exploit the cross-country nature of our dataset to examine whether convertible debt offering policies are influenced by the levels of creditor and shareholder protection offered by local commercial laws. We find that companies domiciled in countries with less shareholder-friendly business laws are more likely to substitute equity-like convertible debt for equity. Hence, we can conclude that the few equity-like convertibles in the Western European convertible debt universe serve to alleviate economy-wide and country-specific equity-related costs, rather than to mitigate firm-specific adverse selection costs. 


\section{References}

Abhyankar, A. and Dunning, A., 'Wealth effects of convertible bond and convertible preference share issues: an empirical analysis of the UK market', Journal of Banking and Finance, Vol. 23, 1999, pp. 1043-65.

Ammann, M., Fehr, M. and Seiz, R., 'New evidence on the announcement effect of convertible and exchangeable bonds', Journal of Multinational Financial Management, Vol. 16, 2006, pp. 43-63.

Ammann, M., Kind, A. and Wilde, C., 'Are convertible bonds underpriced? An analysis of the French market', Journal of Banking and Finance, Vol. 27, 2003, pp. 635-53.

Artis, M.J. and Zhang, W., 'International business cycles and the ERM: is there a European business cycle?', International Journal of Finance and Economics, Vol. 2, 1997, pp. 1-16.

Bancel, F. and Mittoo, U.R., 'Why do European firms issue convertible debt?', European Financial Management, Vol. 10, 2004a, pp. 339-73.

Bancel, F. and Mittoo, U.R, 'Cross-country determinants of capital structure choice: a survey of European firms’, Financial Management, Vol. 33, 2004b, pp. 103-32.

Bayless, M. and Chaplinsky, S., 'Is there a window of opportunity for seasoned equity issuance?', Journal of Finance, Vol. 51, 1996, pp. 253-78.

Billingsley, R.S., Lamy, R.E. and Thompson, G.R., 'The choice among debt, equity, and convertible bonds', Journal of Financial Research, Vol. 11, 1988, pp. 43-55.

Billingsley, R.S. and Smith, D.M., 'Why do firms issue convertible debt?', Financial Management, Vol. 25, 1996, pp. 93-99.

Brennan, M. and Kraus, A., 'Efficient financing under asymmetric information', Journal of Finance, Vol. 42, 1987, pp. 1246-60.

Brennan, M. and Schwartz, E., 'The case for convertibles', Journal of Applied Corporate Finance, Vol. 1, 1988, pp. 55-64.

Brigham, E., 'An analysis of convertible debt: theory and some empirical evidence', Journal of Finance, Vol. 21, 1966, pp. 35-54.

Brounen, D., de Jong, A. and Koedijk, K., 'Corporate finance in Europe: confronting theory with practice’, Financial Management, Vol. 33, 2004, pp. 71-101. 
Burlacu, R., 'New evidence on the pecking order hypothesis: the case of French convertible bonds', Journal of Multinational Financial Management, Vol. 10, 2000, pp. 439-59.

Chang, S.-C., Chen, S.-S. and Liu, Y., 'Why firms use convertibles: a further test of the sequential-financing hypothesis', Journal of Banking and Finance, Vol. 28, 2004, pp. 1163-83.

Choe, H., Masulis, R.W. and Nanda, V., 'Common stock offerings across the business cycle: theory and evidence', Journal of Empirical Finance, Vol. 1, 1993, pp. 3-31.

de Roon, F. and Veld, C., 'Announcement effects of convertible bond loans and warrant-bond loans: an empirical analysis for the Dutch market', Journal of Banking and Finance, Vol. 22, 1998, pp. 1481-1506.

Dutordoir, M. and Van de Gucht, L., 'Are European convertibles more debt-like than the US issues? An empirical analysis’, Working paper (SSRN, 2004).

Essig, S., 'Convertible securities and capital structure determinants', $P h D$ Dissertation (Graduate School of Business, University of Chicago, Chicago, IL 1991).

Gosh, C., Varma, R. and Woolridge, J.R., 'An analysis of exchangeable debt offers', Journal of Financial Economics, Vol. 28, 1990, pp. 251-63.

Graham, J.R. and Harvey, C.R., 'The theory and practice of corporate finance: evidence from the field', Journal of Financial Economics, Vol. 60, 2001, pp. 187243.

Green, R., 'Investment incentives, debt, and warrants', Journal of Financial Economics, Vol. 13, 1984, pp. 115-36.

Hovakimian, A., Opler, T. and Titman, S., 'The debt-equity choice', Journal of Financial and Quantitative Analysis, Vol. 36, 2001, pp. 1-24.

Jung, K., Kim, Y.-C. and Stulz, R.M., 'Timing, investment opportunities, managerial discretion, and the security issue decision', Journal of Financial Economics, Vol. 42, 1996, pp. 159-85.

Korajczyk, R.A. and Levy, A., 'Capital structure choice: macroeconomic conditions and financial constraints', Journal of Financial Economics, Vol. 68, 2003, pp. 75109.

Korkeamaki, T.P., 'Effects of law on corporate financing practices - international evidence from convertible bond issues', Journal of Corporate Finance, Vol. 11, 2005, pp. 809-31. 
Korkeamaki, T.P. and Moore, W.T., 'Convertible bond design and capital investment: the role of call provisions', Journal of Finance, Vol. 59, 2004, pp. 391-405.

Krasker, W.S., 'Stock price movements in response to stock issues under asymmetric information', Journal of Finance, Vol. 41, 1986, pp. 93-105.

Krishnaswami, S. and Yaman, D., 'The role of convertible bonds in alleviating contracting costs', Working Paper (SSRN, 2004).

La Porta, R., Lopez-de-Silanes, F., Shleifer, A. and Vishny, R.W., 'Legal determinants of external finance', Journal of Finance, Vol. 52, 1997, pp. 1131-50.

La Porta, R., Lopez-de-Silanes, F., Shleifer, A. and Vishny, R.W., 'Law and finance', Journal of Political Economy, Vol. 106, 1998, pp. 1113-55.

La Porta, R., Lopez-de-Silanes, F., Shleifer, A. and Vishny, R.W., 'Agency problems and dividend policies around the world', Journal of Finance, Vol. 55, 2000, pp. 133.

Lewis, C.M., Rogalski, R.J. and Seward, J.K., 'Agency problems, information asymmetries, and convertible debt security design', Journal of Financial Intermediation, Vol. 7, 1998, pp. 32-59.

Lewis, C.M., Rogalski, R.J. and Seward, J.K., 'Is convertible debt a substitute for straight debt or for common equity?’ Financial Management, Vol. 28, 1999, pp. 527.

Lewis, C.M., Rogalski, R.J. and Seward, J.K., 'Industry conditions, growth opportunities and market reactions to convertible debt financing decisions', Journal of Banking and Finance, Vol. 27, 2003, pp. 153-81.

Loncarski, I., ter Horst, J. and Veld, C., 'Why do companies issue convertible bonds? A review of theory and empirical evidence', in Renneboog L.D.R., (ed.), Advances in Corporate Finance and Asset Pricing (Amsterdam: Elsevier, 2006).

Lucas, D.J. and McDonald, R.L., 'Equity issues and stock price dynamics', Journal of Finance, Vol. 45, 1990, pp. 1019-43.

Marsh, P., 'The choice between equity and debt: an empirical study', Journal of Finance, Vol. 37, 1982, pp. 121-44.

Mayers, D., 'Why firms issue convertible bonds: the matching of financial and real investment options’, Journal of Financial Economics, Vol. 47, 1998, pp. 83-102.

Myers, S.C. and Majluf, N.S., 'Corporate financing and investment decisions when firms have information that investors do not have', Journal of Financial Economics, Vol. 13, 1984, pp. 187-221. 
Noddings, T.C., Christoph, S.C. and Noddings, J.G., The International Handbook of Convertibles (Chicago: Glenlake, 2001).

Pagano, M., Panetta, F. and Zingales, L., 'Why do companies go public? An empirical analysis', Journal of Finance, Vol. 53, 1998, pp. 27-64.

Pilcher, C.J., 'Raising capital with convertible securities', Michigan Business Studies (University of Michigan, Ann Arbor, MI, 1955).

Stein, J.C., 'Convertible bonds as backdoor equity financing', Journal of Financial Economics, Vol. 32, 1992, pp. 3-21.

Wolfe, S., Daliakopoulos, S. and Gwilym, O.A.P., 'Equity valuation effects of the issuance of convertible bonds: UK evidence', Journal of Fixed Income, Vol. 9, 1999, pp. 7-18.

'2001 ways to use convertibles', Corporate Finance, Vol. 195, 2001, pp. 24-25 (no author mentioned). 


\section{Endnotes}

${ }^{1}$ Western European convertible issuance volume increased from $\$ 1.76$ billion in 1990 to $\$ 19.54$ billion in 2004. For comparison, over the same time span US convertible debt issuance volume rose from $\$ 10.48$ billion to $\$ 35.74$ billion (source: Thomson ONE Banker). Thus, the European convertible market seems to be rapidly catching up with the US market.

${ }^{2}$ Next to the pan-Western European analyses of Bancel and Mittoo (2004a,b), there are also some studies analyzing convertibles issued in individual Western European countries. de Roon and Veld (1998) examine Dutch convertibles, Abhyankar and Dunning (1999) and Wolfe et al. (1999) investigate UK convertibles, Burlacu (2000) studies French convertibles, and Ammann et al. (2006) examine German and Swiss convertibles. However, these studies focus on the stock price effects of convertible debt offering announcements rather than on the issuer motivations behind these offerings.

${ }^{3}$ Lewis et al. (1999) only consider the sweetened debt rationale of Green (1984). In this paper, by contrast, we also consider the rationales of Brennan and Kraus (1987), Brennan and Schwartz (1988), and Mayers (1998). The reason why is that, as noted earlier, the empirical proxies that can be used for capturing the different debt-related financing costs considered by the sweetened debt rationales on convertible debt are largely similar. Therefore, we can only test the joint validity of these four rationales. Some recent empirical studies (Chang et al., 2004; Korkeamaki and Moore, 2004) specifically test the validity of Mayers' (1998) rationale by studying financing patterns around convertible debt calls. Our study focuses on determinants that are observable at the moment of the security offering decision, however.

${ }^{4}$ See Loncarski et al. (2006) for an extensive overview of empirical evidence regarding convertible debt issuance motivations.

${ }^{5}$ See Korkeamaki (2005) for an overview of the literature on the influence of business laws on financing choices.

${ }^{6}$ The German interest rate plays a leading role in the European economy (Artis and Zhang, 1997), hence our choice for the yield on a German Treasury Bond as a measure for the general interest rate level in Western Europe. Our findings are robust to the use of other yield measures (e.g., the 10-year German Treasury Bond yield, the 5-year US Treasury Bond yield, etc.). Results of all robustness checks described throughout the paper are available upon request.

${ }^{7}$ As there is no reason to exclude offerings that do not fulfill the sample selection criteria from the issuance volume calculations, we base these calculations on the initial straight debt and equity samples downloaded from Bloomberg (not on the final samples used in the security choice analyses). The moving average for a straight debt offering made in month $t$ is determined as (number of Western European straight debt offerings in month t-3 + number of Western European straight debt offerings in month t-2 + number of Western European straight debt offerings in month t-1)/3. For equity offerings, calculations are analogous. Hence, there is no endogeneity problem since we only use issuance data from before the issue month.

${ }^{8}$ We obtain similar results when we use the predicted conversion probability obtained from the first step instead of the actual conversion probability to subdivide the convertible debt sample into debt-like and equity-like offerings. 
${ }^{9}$ Bancel and Mittoo (2004b), by contrast, examine firms that have 'seriously considered issuing convertible debt over the past ten years'. These firms do not necessarily coincide with the actual convertible debt issuers examined in our paper. 
Table 1

Overview of empirical evidence regarding the motivations for convertible debt offerings

This table displays the results of prior empirical papers on the motives for convertible debt offerings. Yes (No) indicates whether the evidence supports (does not support) the model or hypothesis mentioned in the previous column.

\begin{tabular}{|c|c|c|c|}
\hline Paper & Scope & Tested rationales & Evidence \\
\hline $\begin{array}{l}\text { Survey analyses } \\
\text { Pilcher (1955) }\end{array}$ & US & $\begin{array}{c}\text { Delayed equity viewpoint) } \\
\text { Sweetened debt viewpoint } \\
\text { (no specific theories mentioned) }\end{array}$ & $\begin{array}{l}\text { Yes } \\
\text { No }\end{array}$ \\
\hline Brigham (1966) & US & $\begin{array}{c}\text { Delayed equity viewpoint } \\
\text { Sweetened debt viewpoint } \\
\text { (no specific theories mentioned) }\end{array}$ & $\begin{array}{l}\text { Yes } \\
\text { No }\end{array}$ \\
\hline Billingsley and Smith (1996) & US & $\begin{array}{l}\text { Delayed equity viewpoint } \\
\text { Sweetened debt viewpoint } \\
\text { (no specific theories mentioned) }\end{array}$ & $\begin{array}{l}\text { Yes } \\
\text { Yes }\end{array}$ \\
\hline Graham and Harvey (2001) & US & $\begin{array}{c}\text { Green (1984) } \\
\text { Brennan and Kraus (1987) } \\
\text { Brennan and Schwartz (1988) } \\
\text { Stein (1992) } \\
\text { Mayers (1998) }\end{array}$ & $\begin{array}{l}\text { No } \\
\text { Yes } \\
\text { Yes } \\
\text { Yes } \\
\text { Yes }\end{array}$ \\
\hline Bancel and Mittoo (2004a) & Europe & $\begin{array}{c}\text { Green (1984) } \\
\text { Brennan and Kraus (1987) } \\
\text { Brennan and Schwartz (1988) } \\
\text { Stein (1992) } \\
\text { Mayers (1998) }\end{array}$ & $\begin{array}{l}\text { Mixed } \\
\text { Mixed } \\
\text { Mixed } \\
\text { Mixed } \\
\text { Mixed }\end{array}$ \\
\hline Bancel and Mittoo (2004b) & Europe & $\begin{array}{c}\text { Green (1984) } \\
\text { Brennan and Kraus (1987) } \\
\text { Brennan and Schwartz (1988) } \\
\text { Stein (1992) } \\
\text { Mayers (1998) }\end{array}$ & $\begin{array}{l}\text { No } \\
\text { No } \\
\text { No } \\
\text { Yes } \\
\text { Yes }\end{array}$ \\
\hline $\begin{array}{l}\text { Quantitative analyses } \\
\text { Lewis et al. (1999) }\end{array}$ & US & $\begin{array}{l}\text { Green (1984) (for debt-like conv.) } \\
\text { Stein (1992) (for equity-like conv.) }\end{array}$ & $\begin{array}{l}\text { Yes } \\
\text { Yes }\end{array}$ \\
\hline Chang et al. (2004) & US & Mayers (1998) & Yes \\
\hline Korkeamaki and Moore (2004) & US & Mayers (1998) & Yes \\
\hline
\end{tabular}


Table 2

Temporal and geographical dispersion of Western European security offerings

The dataset consists of 419 straight debt offerings made by 256 Western European industrial companies, 179 convertible debt offerings made by 148 Western European industrial companies, and 214 equity offerings made by 192 Western European industrial companies. N denotes the number of observations. Panel A presents the number and percentage of security offerings by issue year. Panel B reports the number and percentage of security offerings by sample country.

Panel A: security offerings by issue year

\begin{tabular}{|c|c|c|c|c|c|c|}
\hline \multirow[t]{2}{*}{ Issue year } & \multicolumn{2}{|c|}{ Straight debt } & \multicolumn{2}{|c|}{ Convertible debt } & \multicolumn{2}{|r|}{ Equity } \\
\hline & $\mathrm{N}$ & $\%$ & $\mathrm{~N}$ & $\%$ & $\mathrm{~N}$ & $\%$ \\
\hline 1994 & 11 & $2.63 \%$ & 15 & $8.38 \%$ & 4 & $1.87 \%$ \\
\hline 1995 & 21 & $5.01 \%$ & 2 & $1.12 \%$ & 8 & $3.74 \%$ \\
\hline 1996 & 35 & $8.35 \%$ & 7 & $3.91 \%$ & 26 & $12.15 \%$ \\
\hline 1997 & 37 & $8.83 \%$ & 16 & $8.94 \%$ & 8 & $3.74 \%$ \\
\hline 1998 & 42 & $10.02 \%$ & 16 & $8.94 \%$ & 12 & $5.61 \%$ \\
\hline 1999 & 49 & $11.69 \%$ & 18 & $10.06 \%$ & 14 & $6.54 \%$ \\
\hline 2000 & 45 & $10.74 \%$ & 22 & $12.29 \%$ & 28 & $13.08 \%$ \\
\hline 2001 & 33 & $7.88 \%$ & 18 & $10.06 \%$ & 27 & $12.62 \%$ \\
\hline 2002 & 28 & $6.68 \%$ & 20 & $11.17 \%$ & 40 & $18.69 \%$ \\
\hline 2003 & 27 & $6.44 \%$ & 28 & $15.64 \%$ & 21 & $9.81 \%$ \\
\hline 2004 & 91 & $21.72 \%$ & 17 & $9.50 \%$ & 25 & $11.68 \%$ \\
\hline Total & 419 & $100.00 \%$ & 179 & $100.00 \%$ & 214 & $100.00 \%$ \\
\hline
\end{tabular}

Panel B: security offerings by country of domicile of the issuing firm

\begin{tabular}{lrrrrrr}
\hline Country & \multicolumn{2}{c}{ Straight debt } & \multicolumn{2}{c}{ Convertible debt } & \multicolumn{2}{c}{ Equity } \\
& $\mathrm{N}$ & $\%$ & $\mathrm{~N}$ & $\%$ & $\mathrm{~N}$ & $\%$ \\
\hline Austria & 6 & $1.43 \%$ & 2 & $1.12 \%$ & 7 & $3.27 \%$ \\
Belgium & 5 & $1.19 \%$ & 3 & $1.68 \%$ & 2 & $0.93 \%$ \\
Denmark & 2 & $0.48 \%$ & 1 & $0.56 \%$ & 8 & $3.74 \%$ \\
Finland & 23 & $5.49 \%$ & 6 & $3.35 \%$ & 7 & $3.27 \%$ \\
France & 110 & $26.25 \%$ & 76 & $42.46 \%$ & 26 & $12.15 \%$ \\
Germany & 44 & $10.50 \%$ & 18 & $10.06 \%$ & 24 & $11.21 \%$ \\
Greece & 0 & $0.00 \%$ & 2 & $1.12 \%$ & 0 & $0.00 \%$ \\
Ireland & 1 & $0.24 \%$ & 0 & $0.00 \%$ & 3 & $1.40 \%$ \\
Italy & 28 & $6.68 \%$ & 7 & $3.91 \%$ & 2 & $0.93 \%$ \\
the Netherlands & 26 & $6.21 \%$ & 20 & $11.17 \%$ & 14 & $6.54 \%$ \\
Norway & 25 & $5.97 \%$ & 2 & $1.12 \%$ & 9 & $4.21 \%$ \\
Spain & 8 & $1.91 \%$ & 3 & $1.68 \%$ & 5 & $2.34 \%$ \\
Portugal & 2 & $0.48 \%$ & 0 & $0.00 \%$ & 0 & $0.00 \%$ \\
Sweden & 30 & $7.16 \%$ & 5 & $2.79 \%$ & 10 & $4.67 \%$ \\
Switzerland & 24 & $5.73 \%$ & 20 & $11.17 \%$ & 17 & $7.94 \%$ \\
Unit. Kingdom & 85 & $20.29 \%$ & 14 & $7.82 \%$ & 80 & $37.38 \%$ \\
Total & 419 & $100.00 \%$ & 179 & $100.00 \%$ & 214 & $100.00 \%$ \\
\hline
\end{tabular}


Table 3

Descriptive statistics for Western European straight debt, convertible debt and equity samples

This table reports descriptive firm-specific statistics for samples of straight debt, convertible debt and equity offerings made by Western European industrial companies between 1994 and 2004. The security samples are retrieved from Bloomberg. The straight debt sample consists of 419 offerings, the convertible debt sample consists of 179 offerings, and the equity sample consists of 214 offerings. Firm-specific characteristics are obtained from Datastream and measured at fiscal year-end prior to the security announcement date, unless otherwise indicated. Leverage is total debt divided by total assets. Volatility denotes the standard deviation of the daily stock returns estimated over trading days -240 to -40 relative to the announcement date. Taxes/TA is taxes paid divided by total assets. Slack/TA denotes the sum of cash and marketable securities divided by total assets. Issue Size/MV is the issue size divided by the market value of equity, measured one week prior to the announcement date. Stock Runup is the cumulative stock return, measured over the window $(-75,-1)$ relative to the announcement date. M/B ratio is the market to book ratio, measured as (total assets + market value of equity measured one week prior to the announcement date - book value of equity)/total assets. TA is the book value of total assets. D (D') denotes an (inverse) debt-related cost proxy, E (E) denotes an (inverse) equity-related cost proxy. *,** and *** denote significance at the $0.10,0.05$ and 0.01 levels, respectively.

\begin{tabular}{|c|c|c|c|c|c|c|c|c|c|}
\hline \multirow[t]{2}{*}{ Variable } & \multicolumn{2}{|c|}{$\begin{array}{l}\text { Straight debt } \\
\text { (1) }\end{array}$} & \multicolumn{2}{|c|}{$\begin{array}{l}\text { Convertible debt } \\
\text { (2) }\end{array}$} & \multicolumn{2}{|c|}{$\begin{array}{c}\text { Equity } \\
\text { (3) }\end{array}$} & \multicolumn{3}{|c|}{ t-stat. for pairwise differences in mean values } \\
\hline & Mean & Median & Mean & Median & Mean & Median & $\begin{array}{c}\text { Conv. debt } \\
\text { vs. str. debt } \\
\text { (4) }\end{array}$ & $\begin{array}{l}\text { Conv. debt } \\
\text { vs. equity } \\
\text { (5) }\end{array}$ & $\begin{array}{l}\text { Straight debt } \\
\text { vs. equity } \\
\text { (6) }\end{array}$ \\
\hline Leverage (D) & 0.300 & 0.294 & 0.264 & 0.236 & 0.239 & 0.206 & $-2.66^{* * *}$ & 1.47 & $4.19^{* * *}$ \\
\hline Volatility (D) & 0.021 & 0.019 & 0.030 & 0.028 & 0.032 & 0.028 & $7.74^{* * *}$ & -1.19 & $-8.42^{* * *}$ \\
\hline Taxes/TA (D) & 0.020 & 0.016 & 0.019 & 0.013 & 0.012 & 0.015 & 0.33 & 1.03 & 1.07 \\
\hline Slack/TA (E) & 0.089 & 0.069 & 0.117 & 0.089 & 0.154 & 0.076 & $3.40^{* * *}$ & $-2.47^{* * *}$ & $-4.82^{* * *}$ \\
\hline Issue Size/MV (E) & 0.161 & 0.074 & 0.225 & 0.161 & 0.279 & 0.153 & $2.66^{* * *}$ & -1.61 & $-3.84^{* * *}$ \\
\hline Stock Runup (E') & 0.030 & 0.035 & 0.084 & 0.062 & 0.095 & 0.055 & $2.62^{* * *}$ & -0.39 & $-2.71^{* * *}$ \\
\hline $\mathrm{M} / \mathrm{B}(\mathrm{D}, \mathrm{E})$ & 1.531 & 1.191 & 2.003 & 1.368 & 3.118 & 1.793 & $3.11^{* * *}$ & $-4.07^{* * *}$ & $-6.31_{* * * *}^{* * *}$ \\
\hline TA (\$ mio) $\left(\mathrm{D}^{-}, \mathrm{E}^{-}\right)$ & $15,086.136$ & $5,969.014$ & $6,034.121$ & $1,087.935$ & $1,874.480$ & 410.412 & $-9.97^{* * *}$ & $4.94^{* * *}$ & $18.16^{* * *}$ \\
\hline
\end{tabular}


Table 4

Analysis of determinants of the choice between straight debt, convertible debt, and equity

This table displays the results of logistic regressions analyzing the determinants of the choice between straight debt, convertible debt, and equity for Western European companies. The straight debt sample consists of 419 offerings, the convertible debt sample consists of 179 offerings, and the equity sample consists of 214 offerings. The dependent variable is the risk-neutral probability that the security will be converted into equity at maturity. Firm-specific determinants are measured at fiscal year-end prior to the announcement date, unless otherwise mentioned. Leverage is total debt divided by total assets. Volatility denotes the standard deviation of the daily stock returns estimated over trading days -240 to 40 relative to the announcement date. Taxes/TA is taxes paid divided by total assets. Slack/TA is the sum of cash and marketable securities divided by total assets. Issue Size/MV is the issue size divided by the market value of equity, measured one week prior to the announcement date. Stock Runup is the cumulative stock return, measured over the window $(-75,-1)$ relative to the announcement date. $\mathrm{M} / \mathrm{B}$ is the market to book ratio, measured as (total assets + market value of equity measured one week prior to the announcement date - book value of equity)/total assets. Ln(TA) is the natural logarithm of the book value of total assets. Leading Indicator is the 6-month leading economic indicator for the European economy, expressed as the average level over the three months prior to the issue month divided by the average value over the 12 months prior to the issue month. TB Yield is the yield on 5-year German Treasury Bonds, expressed as an average value calculated over the three months preceding the issue month. Market Runup is the return over the Datastream European equity market index, calculated over the 60 trading days prior to the beginning of the issue month. Hot Straight Debt (Equity) is a dummy variable equal to one for offerings issued during hot straight debt (equity) windows, with hot straight debt and equity windows determined following the criterion outlined in Bayless and Chaplinsky (1996). Creditorprotect (Shareholderprotect) is a dummy variable equal to one for offerings issued by firms domiciled in a country with a Creditor Rights (Shareholder Rights) Index higher than the sample median. Creditor and Shareholder Rights Index values are obtained from La Porta et al. (1997, 1998). France (UK) is a dummy variable equal to one for issues made by French (UK) firms. D (D) denotes an (inverse) debt-related cost proxy, E ( $\mathrm{E}^{-}$) denotes an (inverse) equity-related cost proxy. Positive regression coefficients indicate that the explanatory variable increases the odds in favor of a more equity-like security type. Wald-statistics are inserted in parentheses. ${ }^{*}, * *$ and $* * *$ denote significance at the $0.10,0.05$ and 0.01 levels, respectively.

\begin{tabular}{|c|c|c|}
\hline Variable & (1) & (2) \\
\hline Intercept & $6.019^{* * *}(43.273)$ & $16.229^{* *}(3.924)$ \\
\hline \multicolumn{3}{|l|}{ Firm-specific determinants } \\
\hline Leverage (D) & $-0.050(0.163)$ & $0.013(0.009)$ \\
\hline Volatility (D) & $13.109^{*}(3.400)$ & $18.231^{* *}(5.103)$ \\
\hline Taxes/TA (D) & $-0.134(0.001)$ & $-3.090(0.456)$ \\
\hline Slack/TA (E) & $0.929(1.436)$ & $1.187(1.914)$ \\
\hline Issue Size/MV (E) & $0.031(0.010)$ & $-0.104(0.085)$ \\
\hline Stock Runup (E”) & $0.550(2.528)$ & $0.552(2.152)$ \\
\hline $\mathrm{M} / \mathrm{B}(\mathrm{D}, \mathrm{E})$ & $0.037(0.661)$ & $-0.016(0.094)$ \\
\hline $\operatorname{Ln}(\mathrm{TA})\left(\mathrm{D}^{-}, \mathrm{E}^{-}\right)$ & $-0.515^{* * *}(80.541)$ & $-0.595^{* * *}(83.633)$ \\
\hline \multicolumn{3}{|l|}{ Economy-wide determinants } \\
\hline Leading Indicator (D-, E) & & $-9.087(1.038)$ \\
\hline TB Yield (D) & & $28.246^{* * *}(8.241)$ \\
\hline Market Runup (E) & & $-1.323(0.740)$ \\
\hline Hot Straight Debt (D`) & & $-0.329(1.888)$ \\
\hline Hot Equity (E-) & & $0.343^{*}(2.750)$ \\
\hline \multicolumn{3}{|l|}{ Country-specific determinants } \\
\hline Creditorprotect (D) & & $0.411(1.804)$ \\
\hline Shareholderprotect (E) & & $-0.417(2.112)$ \\
\hline France & & $0.092(0.057)$ \\
\hline UK & & $1.474^{* * *}(21.075)$ \\
\hline \multicolumn{3}{|l|}{ Classificatory power } \\
\hline Pseudo-R ${ }^{2}:$ & $22.41 \%$ & $28.82 \%$ \\
\hline \% Concordant: & $79.20 \%$ & $82.70 \%$ \\
\hline \% Correctly classified: & $74.50 \%$ & $76.40 \%$ \\
\hline
\end{tabular}


Table 5

Analysis of determinants of the choice between debt-like convertible debt and straight debt

This table displays the results of logistic regressions analyzing the determinants of the choice between debt-like convertible debt and straight debt for Western European companies. Debt-like convertible debt offerings are defined as convertibles with a probability of conversion smaller than the upper quartile of the probability of conversion calculated for the entire convertible debt sample (32.88\%). The straight debt sample consists of 419 offerings, and the debt-like convertible debt sample consists of 135 offerings. The dependent variable takes the value one for debt-like convertible debt, and zero for straight debt. All explanatory variables are defined as outlined above Table 4. $\mathrm{D}^{\left(\mathrm{D}^{-}\right)}$denotes an (inverse) debt-related cost proxy, E ( $\mathrm{E}^{-}$) denotes an (inverse) equity-related cost proxy. Positive regression coefficients indicate that the explanatory variable increases the odds in favor of a debt-like convertible debt offering. Wald-statistics are inserted in parentheses. *, ** and *** denote significance at the $0.10,0.05$ and 0.01 levels, respectively.

\begin{tabular}{|c|c|}
\hline Variable & \\
\hline Intercept & $-10.571(0.658)$ \\
\hline \multicolumn{2}{|l|}{ Firm-specific determinants } \\
\hline Leverage (D) & $-0.175(0.548)$ \\
\hline Volatility (D) & $74.350^{* * *}(36.487)$ \\
\hline Taxes/TA (D) & $2.244(0.092)$ \\
\hline Slack/TA (E) & $1.901(1.561)$ \\
\hline Issue Size/MV (E) & $-1.128(2.391)$ \\
\hline Stock Runup (E) & $1.652^{* * *}(7.115)$ \\
\hline $\mathrm{M} / \mathrm{B}(\mathrm{D}, \mathrm{E})$ & $-0.010(0.015)$ \\
\hline $\operatorname{Ln}(\mathrm{TA})\left(\mathrm{D}^{-}, \mathrm{E}^{-}\right)$ & $-0.512^{* * *}(29.286)$ \\
\hline \multicolumn{2}{|l|}{ Economy-wide determinants } \\
\hline Leading Indicator (D-, E-) & $22.123(2.376)$ \\
\hline TB Yield (D) & $-17.569(1.523)$ \\
\hline Market Runup (E) & $-5.724^{* *}(6.259)$ \\
\hline Hot Straight Debt (D) & $-1.090^{* * *}(8.828)$ \\
\hline Hot Equity (E־) & $0.711^{* *}(6.403)$ \\
\hline \multicolumn{2}{|l|}{ Country-specific determinants } \\
\hline Creditorprotect (D) & $-0.521(1.781)$ \\
\hline Shareholderprotect (E) & $-1.477^{* * *}(12.676)$ \\
\hline France & $1.248^{* *}(6.397)$ \\
\hline UK & $0.676(1.475)$ \\
\hline \multicolumn{2}{|l|}{ Classificatory power } \\
\hline Pseudo-R ${ }^{2}:$ & $29.61 \%$ \\
\hline \% Concordant: & $87.00 \%$ \\
\hline \% Correctly classified: & $83.20 \%$ \\
\hline
\end{tabular}


Table 6

Analysis of determinants of the choice between equity-like convertible debt and equity

This table displays the results of logistic regressions analyzing the determinants of the choice between equity-like convertible debt and equity. Equity-like convertible debt offerings are defined as convertibles with a probability of conversion larger than or equal to the upper quartile of the probability of conversion calculated for the entire convertible debt sample (32.88\%). The equity-like convertible debt sample consists of 44 offerings, and the equity sample consists of 214 offerings. The dependent variable takes the value one for equity-like convertible debt, and zero for equity. All explanatory variables are defined as outlined above Table 4. D (D־) denotes an (inverse) debt-related cost proxy, E ( $\left.E^{-}\right)$denotes an (inverse) equity-related cost proxy. Positive regression coefficients indicate that the explanatory variable increases the odds in favor of an equity-like convertible debt offering. Waldstatistics are inserted in parentheses. *, ** and *** denote significance at the $0.10,0.05$ and 0.01 levels, respectively.

\begin{tabular}{|c|c|}
\hline Variables & \\
\hline Intercept & $-69.032^{* * *}(9.689)$ \\
\hline \multicolumn{2}{|l|}{ Firm-specific determinants } \\
\hline Leverage (D) & $0.386(0.808)$ \\
\hline Volatility (D) & $-131.600^{* * *}(12.600)$ \\
\hline Taxes/TA (D) & $-0.805(0.005)$ \\
\hline Slack/TA (E) & $-1.583(0.488)$ \\
\hline Issue Size/MV (E) & $-0.453(0.299)$ \\
\hline Stock Runup (E) & $0.047(0.002)$ \\
\hline $\mathrm{M} / \mathrm{B}(\mathrm{D}, \mathrm{E})$ & $0.183(1.969)$ \\
\hline $\operatorname{Ln}(\mathrm{TA})\left(\mathrm{D}^{-}, \mathrm{E}^{-}\right)$ & $-0.088(0.228)$ \\
\hline \multicolumn{2}{|l|}{ Economy-wide determinants } \\
\hline Leading Indicator ( $\left.\mathrm{D}^{-}, \mathrm{E}^{-}\right)$ & $72.685^{* * *}(10.153)$ \\
\hline TB Yield (D) & $40.400(2.006)$ \\
\hline Market Runup (E) & $-1.031(0.059)$ \\
\hline Hot Straight Debt (D) & $0.475(0.473)$ \\
\hline Hot Equity (E־) & $-1.333^{* *}(4.206)$ \\
\hline \multicolumn{2}{|l|}{ Country-specific determinants } \\
\hline Creditorprotect (D) & $-1.511^{*}(3.158)$ \\
\hline Shareholderprotect (E') & $-1.871^{*}(2.916)$ \\
\hline France & $2.350^{*}(3.796)$ \\
\hline UK & $-1.043(0.742)$ \\
\hline \multicolumn{2}{|l|}{ Classificatory power } \\
\hline Pseudo-R $\mathrm{R}^{2}$ : & $36.25 \%$ \\
\hline \% Concordant: & $92.20 \%$ \\
\hline \% Correctly classified: & $88.80 \%$ \\
\hline
\end{tabular}




\section{Appendix}

The specific selection criteria imposed on the individual security samples are as follows:

- Exclude exchangeable bonds from the convertible debt sample:

As shown by Gosh et al. (1990), issuer motivations for exchangeable offerings (i.e., bonds convertible into shares of a firm other than the issuing company) are substantially different from issuer motivations for convertible offerings. We thus eliminate the exchangeable bonds from the convertible debt sample.

- Exclude secondary equity offerings:

Secondary equity offerings represent no new capital and are thus likely to be driven by substantially different factors than primary equity offerings. Hence, we do not include these offerings in the final sample.

- Exclude issues of different security types made by the same firm during the same fiscal year:

Within our initial dataset, there are several observations involving two or more different financing instruments issued by the same firm during the same fiscal year. We count 46 dual straight debt-equity issues, 40 dual convertible debtstraight debt issues, 16 dual convertible debt-equity issues, and 13 triple straight debt, convertible debt, and equity issues. In line with Hovakimian et al. (2001), we remove these dual and triple security issues from the dataset. This operation makes the logistic regression results more easily interpretable, since only exclusive financing choices are included. Our findings remain qualitatively similar, however, when we leave the dual and triple offerings in the sample. 


\section{Publications in the Report Series Research ${ }^{*}$ in Management}

\section{ERIM Research Program: "Finance and Accounting"}

\section{6}

Valuation Biases, Error Measures, and the Conglomerate Discount Ingolf Dittmann and Ernst Maug

ERS-2006-011-F\&A

http://hdl.handle.net/1765/7592

The economic consequences of IFRS: The impact of IAS 32 on preference shares in the Netherlands Abe de Jong, Miguel Rosellón and Patrick Verwijmeren ERS-2006-021-F\&A http://hdl.handle.net/1765/7688

Do Sophisticated Investors Believe in the Law of Small Numbers? Guillermo Baquero and Marno Verbeek ERS-2006-033-F\&A http://hdl.handle.net/1765/7875

Are There Windows of Opportunity for Convertible Debt Issuance? Evidence for Western Europe Marie Dutordoir and Linda van de Gucht ERS-2006-055-F\&A

http://hdl.handle.net/1765/8044

Why Do Western European Firms Issue Convertibles Instead of Straight Debt or Equity? Marie Dutordoir and Linda Van de Gucht ERS-2006-056-F\&A

http://hdl.handle.net/1765/8043

Learning About the Term Structure and Optimal Rules for Inflation Targeting Mewael F. Tesfaselassie, Eric Schaling and Sylvester C.W. Eijffinger ERS-2006-058-F\&A

http://hdl.handle.net/1765/8042

The Impact of Client Gender, Perceived Client Expertise \& Auditor Gender on Auditors' Judgments Anna Nöteberg, James E. Hunton and Mohamed Gomaa

ERS-2006-059-F\&A

http://hdl.handle.net/1765/8100

* A complete overview of the ERIM Report Series Research in Management: https://ep.eur.nl/handle/1765/1

ERIM Research Programs:

LIS Business Processes, Logistics and Information Systems

ORG Organizing for Performance

MKT Marketing

F\&A Finance and Accounting

STR Strategy and Entrepreneurship 